\section{A Crystalline Serum Muco-Protein with High Choline-Esterase Activity}

IN a recent article ${ }^{1}$, Bader, Schütz and Stacey state: "It appears to be an undecided question whether choline-esterases from different tissues, such as blood and brain, are identical".

Bader and his associates must have failed to note that it has definitely been established that the cholinesterases from different tissues are not identical. The investigations reported by us ${ }^{2}$ have conclusively demonstrated the existence of two distinct cholinesterases, a specific or true cholinesterase and a nonspécific or pseudo-cholinesterase. Erythrocytes and brain $^{3}$ throughout the vertebrate kingdom contain true cholinesterase only, while a mixture of both enzymes is present in most of the sera $^{4}$ and tissues ${ }^{3}$ of the many mammals investigated.

Furthermore, Bader and his co-workers report that they have isolated from horse serum a crystalline muco-protein with a cholinesterase activity 20-25 times higher than that of the original serum. As the purified enzyme preparations from horse serum described by one of us ${ }^{5}$ are about three hundred times more active than their crystals, it seems likely that at least 299 out of 300 parts of these crystals, that is, $99 \cdot 7$ per cent, represent inert material.

Since Bader et al. are inclined to the view that the great discrepancy between their results and our own might be due to the use of different methods of assay, we feel that an exchange of samples, giving both parties an opportunity of comparing the activity of the two preparations by their own test, would be the most satisfactory solution of the controversy.

B. Mendel.

H. RUDNEY.

F. Strexitz.

Sub-Department of Cellular Physiology,

Banting and Best Department of Medical Research, University of Toronto.

1 Bader, R., Schütz, F., and Stacey, M., Nature, 154, 183 (1944). 2 Mendel, B., and Rudney, H., Biochem. J., 37, 59 (1943).

'Mendel, B., and Rudney, H., Science, 98, 201 (1943).

'Mendel, B., Mundell, D., and Rudney, H., Biochem. J., 37, 473 (1943).

s Strelitz, F., Biochem. J., 38, 86 (1944).

\section{An Effect of Overdosage with Cortico- trophic Pituitary Extract on the Rat Kidney}

RECENT progress in the purification of the corticotrophic fraction of the anterior pituitary lobe (the preparations contain 24-48 cortic-lipoid units per mgm.) has made it possible to inject rats with very large doses of this hormone. While investigating the effect of such large doses, it was noticed that the kidneys of animals intraperitoneally injected with a dose exceeding 100 units presented a picture which differed considerably from that of the kidneys of the control rats.

Kidneys of rats injected with the corticotrophic hormone showed the following abnormalities. Macroscopically, the kidneys appear pale, mottled and swollen, with a tense capsule. This observation was borne out by a comparison of the weight of kidneys of injected animals with that of the kidneys of controls. It will be seen from the accompanying table that, after injection of doses of corticotrophic hormone ranging from 4 to $24 \mathrm{mgm}$., weight increases of 14-46 per cent have been found.

\begin{tabular}{|c|c|c|c|c|c|}
\hline Treatment & $\begin{array}{l}\text { No. } \\
\text { of } \\
\text { rats }\end{array}$ & $\begin{array}{c}\text { Combined } \\
\text { body } \\
\text { weight of } \\
\text { whole } \\
\text { group } \\
\text { (gm.) }\end{array}$ & $\begin{array}{l}\text { Combined } \\
\text { weight of } \\
\text { kidneys } \\
\text { (gm.) }\end{array}$ & $\begin{array}{c}\text { Combined } \\
\text { weight of } \\
\text { kidneys as } \\
\text { per cent of } \\
\text { combined } \\
\text { body } \\
\text { weight }\end{array}$ & $\begin{array}{l}\text { Increase } \\
\text { in kidney } \\
\text { weight } \\
\text { (per cent) }\end{array}$ \\
\hline $\begin{array}{l}\text { Controls } \\
24 \text { hours } \\
\text { after } \\
8 \mathrm{mgm} \text {. } \\
\text { intraperit. }\end{array}$ & 3 & 125 & 1.77 & $1 \cdot 41$ & +35.5 \\
\hline $\begin{array}{l}\text { Controls } \\
5 \text { hours after } \\
4 \mathrm{mgm} \text {. } \\
\text { intraperit. } \\
3 \times 44 \mathrm{mgm} \text {. } \\
\text { in } 48 \text { hours }\end{array}$ & $\begin{array}{l}3 \\
3\end{array}$ & $\begin{array}{l}145 \\
126\end{array}$ & $\begin{array}{l}2 \cdot 45 \\
2 \cdot 38\end{array}$ & $\begin{array}{l}1.69 \\
1.89\end{array}$ & $\begin{array}{l}+32 \\
+46.5\end{array}$ \\
\hline $\begin{array}{c}\text { Controls } \\
3 \times 4 \mathrm{mgm} \text {. } \\
\text { in } 48 \text { hours } \\
6 \times 4 \text { mgm. } \\
\text { in } 72 \text { hours } \\
5 \text { hours } \\
\text { after } \\
12 \mathrm{mgm} \text {. } \\
\text { intraperit. }\end{array}$ & $\begin{array}{l}3 \\
3 \\
3\end{array}$ & $\begin{array}{l}129 \\
122 \\
133\end{array}$ & $\begin{array}{l}1 \cdot 8 \\
2 \cdot 1 \\
2 \cdot 6\end{array}$ & $\begin{array}{l}1 \cdot 39 \\
1 \cdot 68 \\
1.92\end{array}$ & $\begin{array}{l}+22 \cdot 4 \\
+38 \cdot 1\end{array}$ \\
\hline
\end{tabular}

Histological findings. In kidneys of rats injected with I mgm. of extract per animal and killed after 12 hours, the main pathological change consists in a patchy necrosis of the tubules of the glomerular zone of the cortex (see photomicrograph). There is marked swelling of the tubular epithelium, usually sufficient to obliterate the lumen, nuclei are absent or shrunken and pyknotic, and the cytoplasm stains a light pink with eosin without showing the granularity of cloudy swelling. Staining with Sudan III or IV shows deposits of lipoid granules in a minority of these tubules; but fatty change is not a conspicuous feature, nor do these kidneys contain anisotropic lipoid. The glomeruli are somewhat enlarged and may exhibit a slight cellular swelling and capillary dilatation. With larger doses (for example, $8 \mathrm{mgm}$. after 12 hours) in addition to the changes described above, which are now more marked in the case of the glomeruli, there are larger areas of infarction, with necrosis of all elements of the cortex, corresponding to the areas of hæmorrhage abserved macroscopically.

The changes described could be seen as early as five hours after injection of the high doses of the corticotrophic hormone, and they seem to be fully developed twelve hours after the hormone administration.

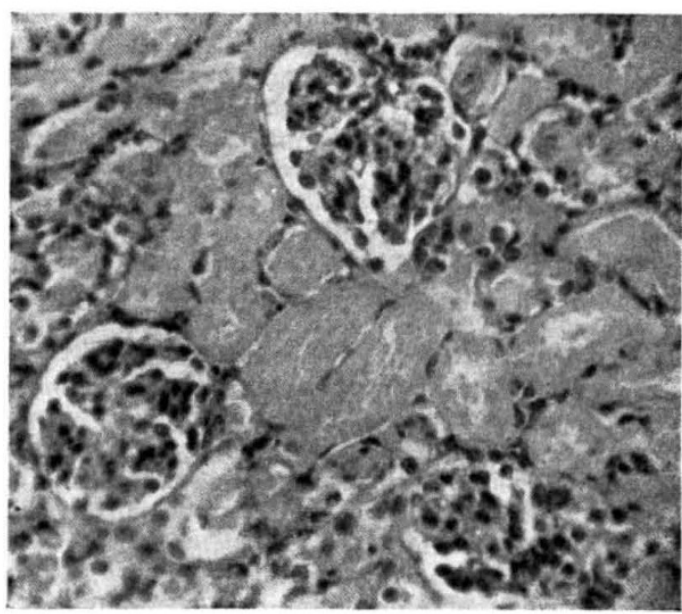

NECROSIS OF TUBULES IN THE GLOMERULAR ZONR OF THR CORTRX OF RAT KIDNEY 12 HOURS AFTER 1 MGM. EXTRACT INTRAPRRITONEALLY. EHRLIOH'S HAMATOXYLIN AND EOSIN. $\times 270$. 